\title{
Commentary
}

\section{Planning for Planet or City?}

\author{
Mark Davidson
}

Geography Department, Clark University, MA 01610, Worcester, USA; E-Mail: mdavidson@clarku.edu

Submitted: 17 February 2016 | Accepted: 18 February 2016 | Published: 3 March 2016

\begin{abstract}
If we now live with a planetary urban process (Brenner \& Schmid, 2015a), the very idea of "future cities" must be brought into question. Indeed, we might ask whether urban planning has morphed into planetary planning, with its primary charge being the construction of vast networks of urban systems coordinating a global capitalist process. This commentary cautions against such over-extended theories of urbanization and related planning practices. Although global capitalism has engendered profound spatial changes, the concept of the city remains a crucial social and political idea. By outlining the continued centrality of the city to social and political life, the commentary argues for a democratic evaluation of the urban form in order to plan for, and realize, more just cities.
\end{abstract}

\section{Keywords}

future cities; urban forms; urban planning; urbanization

\section{Issue}

This commentary is part of the issue "Urban Forms and Future Cities", edited by Luca D'Acci (Erasmus University Rotterdam, The Netherlands), Tigran Haas (KTH Royal Institute of Technology, Sweden) and Ronita Bardhan (Indian Institute of Technology Bombay, India).

(C) 2016 by the author; licensee Cogitatio (Lisbon, Portugal). This article is licensed under a Creative Commons Attribution 4.0 International License (CC BY).

\section{No More Cities on Planet Earth?}

"Society has been completely urbanized. This hypothesis implies a definition: An urban society is a society that results from a process of complete urbanization. This urbanization is virtual today, but will become real in the future" (Lefebvre, 1970/2003 1)

The concept of "planetary urbanization" has become popularized across the urban studies literatures (e.g. Brenner \& Schmid, 2015a; Harvey, 2014; Merrifield, 2013). The concept is drawn from Lefebvre's (1970/2003) prophetic theorizations in The Urban Revolution. In this slim book, Lefebvre somewhat ironically claims (Merrifield, 2013) that society is becoming completely urbanized: talk of cities could be replaced by talk of urban societies. If we fast-forward some forty years, it is perhaps unsurprising to find some urbanists claiming that Lefebvre's provocative thesis has been realized. Since the 1970s, a whole set of social, political and economic changes, often collected up under the term globalization, have reshaped the capitalist landscape. On almost all measures, the prominence of cit- ies, and their inter-relations, have become more significant to life across the globe. For example, since 1980 goods and commercial services, produced principally within city-regions, exchanged across the globe have grown in value from \$2.31tn to \$22.27tn in 2011 (World Trade Organization, 2013). The planet is also enmeshed in a communication network that currently has $40 \%$ of the global population hooked up to the internet. ${ }^{1}$

The documenting of urbanization's very own globalization provides a stimulus for Brenner and Schmid's (2015a, 2015b) recent rethinking of urban theory. In their "new urban epistemology" they present a significant challenge to all urban scholars:

"If the urban is no longer coherently contained within or anchored to the city-or, for that matter, to any other bounded settlement type-then how can a scholarly field devoted to its investigation continue to exist? Or, to pose the same question as a challenge of

\footnotetext{
${ }^{1}$ Such statistics and associated geographical transformations are central to the work conducted at Harvard University's Urban Theory Lab (http://www.urbantheorylab.net).
} 
intellectual reconstruction: is there-could there be-a new epistemology of the urban that might illuminate the emergent conditions, processes and transformations associated with a world of generalized urbanization?" (Brenner \& Schmid, 2015a, p. 155)

In their subsequent attempt to develop a new urban epistemology, they generate a toolbox of concepts that attempt to capture the "moments" and "dimensions" of urbanization. Moments of urbanization include "concentrated", "extended" and "differential" urbanization. Dimensions of urbanization are "spatial practices", territorial regulation" and "everyday life" (Brenner \& Schmid, 2015a, p. 171). The resultant matrix of urbanization offers a powerful analytical device with which to generate an understanding of contemporary urbanization processes. Provocatively, it also enables us to drop the term "city" from the urban studies lexicon, since references to such a bounded entity are replaced by a conceptual framework that sees an unbounded, but differentiated, urban landscape.

The extent to which Brenner and Schmid's (2015a) new urban epistemology transforms our thinking about cities and urbanization depends on which version of their theory you wish to engage with. There is both a modest and a more strident version of this new urban epistemology (see Davidson \& Iveson, 2015a). In the modest version, Brenner and Schmid's epistemology warns against the city-centrism of urban theory and, in doing so, urges us to pay more attention to the dimensions of urbanization that are not contained or conditioned by the "city" (also see Harvey, 2014). In the stronger version of their epistemology Brenner and Schmid (2015a) seek to dispense of the concept of the city altogether, principally by arguing that there is nothing like a "non-city" space outside of the urban fabric. The city is therefore replaced by "'concentrated urbanization' and agglomeration" in which there are no "distinct morphological conditions, geographical sites or temporal stages" but rather they are wrapped up in a process of sociospatial transformation that is both without borders and inherently urban (Brenner \& Schmid, 2015a, p. 169 cited in Davidson \& Iveson, 2015a, p. 651).

If we take the stronger version of Brenner and Schmid's (2015a) argument and apply it to questions of urban planning, its implications are extensive. It would mean, for example, that urban planning would certainly supersede any remaining notions of city planning. It would also mean that urban planning for defined urban spaces (i.e. the city) becomes a very limited activity-if not completely irrelevant-since the constitutive properties and processes of "city" space extend far beyond any identifiable boundaries. Although this line of argument remains important in the context of an ongoing social and politico-economic transformation of the city, the over-extension of idea of planetary urbanization brings with it significant dangers. In particular, the fundamental connection between politics and the city can get lost within attempts to conceptualize the implosions and explosions of planetary urbanization.

\section{City and Politics}

Within a world of global communications, international trade and increased (for some) mobility, the persistent relevance of the city to theory and practice does require explanation. On the one hand, you might explain a persistent concern with "the city" as a manifestation of out-dated theory (Brenner \& Schmid, 2015a), the remains of previous forms of city-based collectivism or stubborn institutions of governance. On the other hand, there are compelling reasons why the city remains crucial to contemporary social life. Most significantly, the city remains important today since it continues to serve as an entity that constitutes and is constitutive of politics.

I am defining politics in the restrictive sense set out by Jacques Rancière (1999, p. 5): "The political begins precisely when one stops balancing profits and losses and worries instead about distributing common lots and evening out communal shares and entitlements to these shares, the axiai entitling one to community". For Rancière, politics happen when the equality of all within a community-the foundational premise of democratic societies; and the only philosophically legitimate form of government (Rancière, 1999, p. 1)-is tested by the enunciation of an inequality claim. Rather than politics being about social conflict per se, politics occurs in those conflicts that question how the parts of any order are distributed: "For political philosophy to exist, the order of political identities must be linked to some construction of city "parts", to a count whose complexities may mask a fundamental miscount, a miscount that may well be the blaberon, the very wrong that is the stuff of politics" (Rancière, 1999, p. 6). Rancière's reference to city parts is important because it helps to signal to the close relationship between politics and the city.

Of course, the idea of planetary urbanization can pose a significant challenge to the relationship between urban community and politics: if city life no longer corresponds to urban life, how does the city provide any foundation for politics? And yet, a cursory look across the contemporary political landscape reveals how the idea of "the city" remains critical to politics today. For example, across the flash points of the Arab Spring, revolutionary moments were formed when peoples claimed a right to their cities (Davidson \& Iveson, 2014); where forms of political equality were claimed (and, in many places, subsequently denied). A similar urbanizing of political concerns can be found in debates over growing social and income inequality. Although this corrosive trend is evidently a global phenomenon, more often than not, related protests and 
reform agendas are presented within the context of cities. It is not that the debate participants simply have the wrong urban epistemology, but rather it is the case that politics very often play out within certain, and with reference to, (urban) political communities. Rather than seeing the city as less important to politics, the challenge has become concerned with what Doreen Massey calls a politics of place beyond place (2007): how can our communally-based political actions reach beyond the immediacy of the community?

One possible solution is to view the (bounded) city as always in dialectical relations with the (planetary) urban (see Davidson \& Iveson, 2015a, 2015b). Politics can transcend particularities of space and time not only through a tracing out of the global processes that constitute them, they can also become more-than-citycentric through an identification of the universal qualities of politics; namely the philosophical foundations of democratic politics (Rancière, 1999). While subjectification and social conflicts will always be particular, the organization of particularities with regards to the universal foundations of politics makes it possible to transcend the context within which subjects and conflicts emerge (Davidson \& Iveson, 2015a, p. 662).

\section{City Form and the Future}

If the city remains central to politics, it means we should remain concerned with the processes that construct the city and its citizens. The current attempt to develop an understanding of the planetary urbanization process (Brenner \& Schmid, 2015a) should therefore be supplemented and mediated by a philosophical and theoretical (re)engagement with city politics. We must develop methods which make it possible to differentiate political claims from other types of claims within the places that they emerge (see Davidson \& Iveson, 2015b) and begin a process of re-installing politics within city life. Without such an effort, any political insights generated from the study of planetary urbanization will likely remain academic abstractions. Of course, a concern about the decline of certain forms of politics has been with us for some time (e.g. Sennett, 1974). In recent years, this concern has been manifest in arguments about the purely technocratic scope of contemporary politics and government (see Swyngedouw, 2010). And although these recent arguments about the absence of politics can seem to divert attention from attempts to reignite politics, the latter should be considered the urgent task.

Here a dialog between urban theorists and urban planners can play an important role. If today we witness an overwhelming technocratic form of governance that denies people the right to articulate those types of disagreements that constitute politics, the ways in which we approach questions of city form and urban planning can become tools through which we support the enactment of (democratic) politics. The possible types of contribution are numerous, so I will briefly offer a couple of illustrative examples.

If the bounded thing we call "the city" still matters to urban theory and politics, we should be concerned with the common lots of the city. Since politics revolve around a concern with what is held in common, and political equality defines how these commons are allocated, then urban planners themselves have a criteria with which to access the democratic efficacy of their activities. Although Rancière (1999) discusses equality principally in terms of democratic/political equality, there is important work to be done in accessing how the contemporary urban form enables or restricts the political equality of citizens. Rancière himself discusses how the categorization of certain peoples and places can serve to deny them a political voice. In places like Paris, this has often been achieved through the governmental designation and characterization of places like the banlieues (Dikec, 2007). This carving up of the city and categorization of spaces and peoples has often served to erase the political equality of peoples. The particularities of identity and neighborhood can here be used to make claims about social inequality (i.e. politics) the subject of targeted and un-relational state interventions. By this, I mean to say that state intervention is framed in such a manner that the city-wide constitutive processes that generate the social inequality are never themselves subject to politics. The designations that define and identify such placesregeneration, renewal, slum clearance, problem estates and so on-likely need to be replaced with other forms of spatial understanding and visualization. We could perhaps here learn something from utopians like Ebenezer Howard, where the prescription of city form provided a powerful basis for political representation/subjectification. In the likes of the Garden City Movement you find foundational images of city form providing a standard by which to assess and critique existing designations (i.e. how everyone relates to the general purpose of the city).

Finally, it is crucial to recognize that in democratic societies, politics are possible in all places and all times. That is to say, an equality claim (i.e. a claim that some part of the city/community is unequal) can emerge at any time and in any space. Politics are therefore not reserved for government chambers or even public spaces. When Rosa Parks refused to move seats on the number 2857 Montgomery city bus, her actions transcended the confines of the bus precisely because her actions presented a powerful equality claim (Rancière, 1999). This act of politics did not rely on a public space or meeting hall. Rather, an expression of (democratic) equality required all of the particularities of the bus seat. If urbanists of all stripes make ourselves aware of how political claims can constitute themselves in this way, the implications for urban planning and urban 
theory are extensive. They include the acknowledgment that politics cannot be assigned to any one part of the city, even if certain spaces can act as symbolic sites of politics (see Davidson \& Iveson, 2015b).

A concern with city form might therefore be pivotal to how we tackle the overwhelming nature of planetary urbanization.

\section{Acknowledgments}

The arguments developed in this paper have benefitted immensely from my ongoing collaboration with Kurt Iveson.

\section{Conflict of Interests}

The author declares no conflict of interests.

\section{References}

Brenner, N., \& Schmid, C. (2015a). Towards a new epistemology of the urban? City, 19(2/3), 151-182.

Brenner, N., \& Schmid, C. (2015b). Combat, caricature \& critique in the study of planetary urbanization. Retrieved from http://www.soziologie.arch.ethz.ch/ _DATA/90/BrennerSchmid2.pdf

Davidson, M., \& Iveson, K. (2014). Occupations, mediations, subjectifications: Fabricating politics. Space and Polity, 18(2), 137-152.

Davidson, M., \& Iveson, K. (2015a). Beyond city limits.
City, 19(5), 646-664.

Davidson, M., \& Iveson, K. (2015b). Recovering the politics of the city. Progress in Human Geography, 39(5), 543-559.

Dikec, M. (2007). Badlands of the republic. Oxford, UK: Blackwell.

Harvey, D. (2014). The crisis of planetary urbanization. Retrieved from http://post.at.moma.org/content items/520-the-crisis-of-planetary-urbanization

Lefebvre, H. (2003). The urban revolution. Minneapolis, MN: University of Minnesota Press. (Original work published 1970)

Massey, D. (2007). World city. Cambridge, UK: Polity Press.

Merrfield, A. (2013). The urban question under planetary urbanization. International Journal of Urban and Regional Research, 37(3), 909-922.

Ranciere, J. (1999). Disagreement: Politics and philosophy. Minneapolis, MN: University of Minnesota Press.

Sennett, R. (1974). The fall of public man. New York: W.W. Norton.

Swyngedouw, E. (2010). Apocalypse forever? Postpolitical populism and the spectre of climate change. Theory, Culture \& Society, 27(2/3), 213-232.

World Trade Organization. (2013). World trade report 2013. Location: World Trade Organization. Retrieved from https://www.wto.org/english/res_e/ booksp_e/wtr13-2b_e.pdf

\section{About the Author}

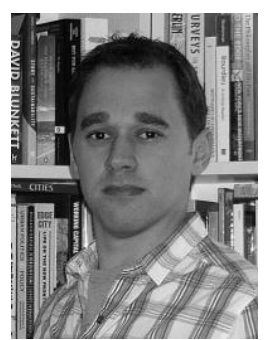

\section{Dr. Mark Davidson}

Mark Davidson is an Associate Professor of Geography at Clark University. He is an urban geographer whose research interests span gentrification, urban policy, society and community and metropolitan development, planning and architecture. His current research is examining the impacts of municipal bankruptcies in the United States and includes an attempt to re-theorize critical urban theory. He has held fellowships at the Nelson A. Rockefeller Centre for Public Policy and Social Science, Dartmouth College, and the Urban Research Centre, University of Western Sydney. He holds a BA (Hons) and PhD in Geography from King's College London. 